\title{
PENGARUH EKSISTENSI MASYARAKAT HUKUM ADAT TERHADAP PENGUASAAN TANAH PRABUMIAN BERDASARKAN KONSEPSI KOMUNALISTIK RELIGIUS DI BALI
}

\author{
Made Oka Cahyadi Wiguna \\ Fakultas Hukum Universitas Pendidikan Nasional \\ Dosen Hukum Adat \\ Email: okacahyadi@undiknas.ac.id
}

\begin{abstract}
ABSTRAK
Eksistensi masyarakat hukum adat di Bali sangat mempengaruhi eksistensi penguasaan tanah prabumian berdasarkan konsep komunalistik religius. Konsepsi komunalistik religius adalah konsepsi utama dalam pembangunan tanah nasional untuk mencapai unifikasi hukum tanah nasional. Konsepsi komunalistik religius juga tercermin dalam penguasaan tanah prabumian, desa pakraman di Bali oleh krama desa. Unsur komunalistik terwujud dalam penguasaan tanah tersebut sebagai tempat bermukim dan untuk digarap sehingga memberikan suatu hasil yang dapat dipergunakan untuk menunjang kehidupan sebagai sumber nafkah. Sebagai unsur kebersamaan maka bagian tertentu dari hasil penggarapan tanah yang harus diserahkan kepada desa pakraman untuk kepentingan bersama dalam upacara yadnya dan adanya larangan pengalihan tanah tersebut tanpa ada persetujuan bersama dalam paruman desa pakraman. Mengenai unsur religius tercermin dari adanya suatu kepercayaan bahwa pemerajan dan Pura Kahyangan Tiga di desa yang didirikan di atas tanah prabumian harus tetap dijaga dan dirawat karena dipercayai terdapat kekuatan Ida Sang Hyang Widhi Wasa beserta segala manifestasi-Nya termasuk juga roh para leluhur.
\end{abstract}

Kata Kunci: Komunalistik religius, Tanah Prabumian, Desa Pakraman

\begin{abstract}
The existence of adat law community in Bali significantly affects the control of prabumian land based on the religious communalistic concept. The religious communalistic concept is the initial conception of national land development to achieve unification of national land law. The religious communalistic concept is also reflected in the control of the prabumian land of Pakraman Village in Bali by the Krama Desa (Village Inhabitants). The communalistic element is manifested in the land control as a place for living and cultivation so as to provide an outcome to as a source of life. As an element of togetherness, the particular part of the cultivation yield should be handed over to Pakraman Village as a common interest in Yadnya ceremony, and there is a prohibition of diversion of the land without any consent from Paruman Pakraman Village. Regarding the religious element, it is reflected in the belief of pemerajan and Pura Kahyangan Tiga established above the Prabumian land in the
\end{abstract}


village that must be maintained and cared because it is believed there are an Ida Sang Hyang Widhi Wasa strength and all His manifestations including the ancestors' spirits.

\section{Keywords: religious communalistic, PrabumianLand, Pakraman Village}

\section{A. PENDAHULUAN}

Undang-Undang Republik Indonesia Nomor 5 Tahun 1960 Tentang Peraturan Dasar Pokok-Pokok Agraria yang selanjutnya lebih dikenal dengan UUPA, merupakan landasan yuridis untuk meunifikasi hukum tanah nasional. Unifikasi hukum tersebut ditujukan untuk menghilangkan berlakunya pluralisme hukum yang berlaku terhadap pengaturan mengenai pertanahan yang berlaku sebelum UUPA diberlakukan. Berlakunya pluralisme hukum terhadap ketentuan pertanahan di Indonesia tentunya menimbulkan ketidakpastian hukum bagi masyarakat. Oleh karena itu, unifikasi hukum tanah nasional mempunyai tujuan untuk memberikan kepastian hukum bagi segenap bangsa Indonesia dalam bidang pertanahan.

Telah disepakati bahwa, kehendak bangsa Indonesia untuk meunifikasi hukum tanah nasional didasarkan pada hukum adat, khususnya dalam bidang pertanahan. Hal tersebut menunjukkan bahwa hukumnya masyarakat Indonesia asli mempunyai peran yang cukup strategis dalam pembangunan hukum negara (state law), yang dalam hal ini pembangunan hukum tanah nasional. Sehingga peran dan kedudukan hukum adat dalam pembangunan hukum tanah nasional tersebut melahirkan hubungan fungsional antara hukum adat dengan hukum tanah nasional. Oleh karenanya menurut Urip Santoso "hukum adat tentang tanah mempunyai kedudukan yang istimewa dalam pembentukan hukum agraria nasional" (Santoso, 2010: 65). Berdasarkan hal tersebut di atas, senyatanya tampak jelas bahwa hukum yang berlaku di Indonesia tidak dapat dilepaskan dari pengaruh-pengaruh hukum adat dan bahkan tidak dapat dijauhkan pula dari pengaruh agama yang terkadang mempengaruhi hukum adat.

Adanya suatu ideologi yang dinamakan dengan sentralisme hukum (legal centralism) yang menginginkan berlakunya hukum negara sebagai satu-satunya hukum yang berlaku dan terlepas dari pengaruh pranata hukum lainnya yang mengikat warganya, secara empirik tidak dapat diberlakukan di Indonesia, karena senyatanya hukum adat dan hukum agama sebagai pranata hukum selain hukum negara dianut dan dipatuhi oleh masyarakat (Nurjaya, 2014: 15).

Indonesia sebagai bangsa yang multietnik, ras, agama dan beragam budaya yang tercermin dalam kebhinekaan, dalam banyak hal ternyata mempunyai kesamaan. Pada bidang pertanahan misalnya, sekalipun tersebar di berbagai daerah di nusantara, masyarakat adat mempunyai kesamaan pola dalam hubungannya dengan tanah-tanah komunal yang mereka tempati sebagai lebensraum. Atas dasar tersebut seorang warga masyarakat hukum adat kemudian berhak untuk memanfaatkan tanah tersebut untuk mengumpulkan hasi-hasil hutan, memburu binatang liar yang hidup dalam lebensraum-nya, mengerjakan tanah itu terusmenerus, namun hak tersebut masih dibatasi oleh hak ulayat (Wiguna, 2009: 13). Sehingga kesamaan tersebut kemudian menjadi dasar sekaligus sumber utama dan 
sumber pelengkap dalam pembangunan hukum tanah nasional yang terefleksi dalam hubungan fungsional antara hukum adat dengan hukum tanah nasional.

Menurut Boedi Harsono, dalam pembangunan hukum tanah nasional hubungan fungsional tersebut terwujud dalam fungsi hukum adat sebagai sumber utama yaitu berupa konsepsi, asas-asas dan lembaga hukumnya yang kemudian dirumuskan dengan menggunakan sistem hukum adat dan sebagai sumber pelengkap jika dihubungkan dengan hukum positif mengenai hukum tanah (Harsono, 2008: 205). Salah satu dari beberapa sumber utama pembangunan hukum tanah nasional adalah konsepsi komunalistik religius, yaitu konsep yang menggambarkan bahwa memungkinkan penguasaan tanah komunal masyarakat hukum adat secara individual, dengan hak-hak atas tanah secara pribadi dan penguasaan tersebut masih tetap mengandung unsur kebersamaan.

Konsepsi ini secara tidak langsung sangat berperan penting utamanya dalam merekonstruksi filosofi pola hubungan negara dengan tanah. Di mana sebelumnya jika ditarik secara historis, hubungan negara dengan tanah sebelum Indonesia merdeka adalah semua tanah yang tidak dapat dibuktikan kepemilikan hak atas tanahnya, maka tanah tersebut merupakan milik negara. Kenyataan demikian merupakan suatu implementasi dari prinsip domein verklaring yang berlaku pada zaman Hindia Belanda. Tentu saja prinsip tersebut tidak sesuai lagi diterapkan pasca Indonesia merdeka, karena bersendikan kolonialis. Kemudian pola pemilikan tersebut diubah menjadi pola menguasai seiring dengan disahkannya UndangUndang Dasar Negara Republik Indonesia Tahun 1945 yang kemudian juga sebagai landasan konstitusional dari UUPA. Khususnya dalam ketentuan Pasal 33 ayat (3) yang mengatur bahwa "Bumi, air dan kekayaan alam yang terkandung di dalamnya dikuasai oleh Negara dan dipergunakan untuk sebesar-besarnya kemakmuran rakyat".

Jika berbicara mengenai konsepsi komunalistik religius, tentu tidak akan dapat dilepaskan dari keberadaan tanah-tanah ulayat masyarakat hukum adat di seluruh wilayah Indonesia, tidak terkecuali di Bali. Bali sebagai bagian dari multikulturalnya dan multietniknya Indonesia, secara tidak langsung juga memberikan sumbangsih terhadap pembangunan hukum tanah nasional. Hal itu disebabkan karena secara historis, Bali juga mempunyai banyak masyarakat hukum adat yang mempunyai tanah-tanah ulayat pada masing-masing wilayah desa pakraman di Bali yang disebut dengan tanah desa atau tanah prabumian. Dalam tulisannya S. Hendriatiningsih, A. Budiartha, Andri Hernand menyebutkan bahwa terdapat beberapa jenis tanah adat di Bali yaitu (Hendriatiningsih, Budiartha dan Hernand, 2008: 523):

1. Tanah Druwe atau sering disebut juga Druwe Desa adalah tanah yang dimiliki atau dikuasai oleh desa pakraman seperti Tanah Pasar, Tanah Lapang, Tanah Kuburan,Tanah Bukti,

2. Tanah Pelaba Pura adalah tanah yang dulunya milik desa yang khusus digunakan untuk keperluan Pura yaitu tempat bangunan Pura dan yang 
dipergunakan guna pembiayaan keperluan Pura seperti pembiayaan upacaraupacara rutin, hingga perbaikan pura,

3. Tanah Pekarangan Desa merupakan tanah yang dikuasai oleh desa pakraman yang diberikan kepada krama negak untuk tempat tinggal dengan ayahan yang melekat,

4. Tanah Ayahan merupakan tanah yang dikuasai desa pakraman yang penggarapannya diserahkan kepada krama desa setempat dengan hak untuk dinikmati dengan perjanjian tertentu serta kewajiban memberikan ayahan.

Kemudian, konsepsi komunalistik religius tersebut tumbuh, hidup dan berkembang dalam hubungan krama desa (anggota masyarakat hukum adat) dengan tanah ulayatnya. Atas dasar tersebut, terjadi saling keterkaitan antara krama desa dengan tanah-tanah adatnya. Sehingga eksistensi tanah prabumian di Bali tidak dapat dilepaskan pula dari eksistensi pengaruh masyarakat hukum adatnya.

Berdasarkan pemaparan di atas, penulis tertarik untuk membahas mengenai pengaruh eksistensi masyarakat hukum adat terhadap penguasaan tanah prabumian berdasarkan konsepsi komunalistik di Bali. Kajian ini merumuskan dua rumusan masalah, yaitu:

1. Apakah eksistensi tanah prabumian dipengaruhi oleh eksistensi masyarakat hukum adat (desa pakraman)?

2. Bagaimana pola penguasaan tanah prabumian oleh krama desa pakraman berdasarkan konsepsi komunalistik religius?

\section{B. PEMBAHASAN}

\section{Pengaruh Eksistensi Masyarakat Hukum Adat (Desa Pakraman) Terhadap Eksistensi Tanah Prabumian}

Sebelum membahas lebih mendalam mengenai eksistensi konsepsi komunalistik religius pada penguasaan tanah prabumian di Bali, sangat penting untuk diketahui bersama bahwa, eksistensi desa pakraman sebagai kesatuan masyarakat hukum adat secara tidak langsung akan mendukung eksistensi dari penguasaan tanah-tanah adat baik di Bali. Bali merupakan salah satu daerah yang mempunyai tatanan kehidupan masyarakat hukum adat yang jumlahnya cukup signifikan. Dalam tulisannya I Nyoman Budiana menyebutkan bahwa "Bali sebagai pulau dewata terbagi habis ke dalam 1.473 (seribu empat ratus tujuh puluh tiga) desa pakraman" (Budiana, 2011: 9). Berdasarkan kuantitas desa pakraman tersebut nampak jelas bahwa eksistensi masyarakat hukum adat di Provinsi Bali sangat terjaga.

Eksistensi tanah adat di Bali sejauh ini mayoritas masih tetap bertahan dan bahkan terdapat kecenderungan semakin menguat. Namun tidak dapat dipungkiri juga di beberapa daerah justru eksistensi tanah adat semakin melemah. Melemahnya atau hilangnya eksistensi dari tanah adat tersebut dapat disebabkan oleh faktor internal maupun faktor eksternal. Menurut penulis faktor internal yang mempengaruhi hal tersebut, yang pertama adalah hilangnya eksistensi masyarakat hukum adatnya sendiri. Kedua adalah sangat berhubungan erat dengan 
keberlangsungan masyarakat hukum adat itu sendiri, yaitu menurunnya ketaatan masyarakat hukum adat terhadap peraturan-peraturan hukum adat dan lembaga adatnya. Apabila eksistensi masyarakat hukum adat tersebut telah hilang maka secara tidak langsung juga akan menyebabkan ketentuan-ketentuan hukum adat yang diadakan oleh masyarakat untuk dipatuhi tidak dapat diberlakukan lagi, termasuk juga mengenai ketentuan tanah-tanah prabumiannya akan secara otomatis tidak dapat diberlakukan lagi.

Kemudian, faktor eksternal yang dapat menyebabkan melemahnya atau bahkan menghilangkan keberadaan tanah adat adalah kurang kompeherensifnya pengakuan dalam ius consitutum dari negara terhadap masyarakat hukum adat dan tanah-tanah adat tersebut. Sehingga menyebabkan proteksi dari hukum atas tanahtanah adat secara tidak langsung juga menjadi lemah. Hal ini yang menyebabkan ketika terjadi sengketa pertanahan mengenai tanah adat, acapkali yang dirugikan adalah masyarakat hukum adat yang kedudukan hukumnya sangat lemah terhadap tanah adat yang mereka miliki dan kuasai.

Padahal, dalam ketentuan Pasal 18 B ayat (2) Undang-Undang dasar Negara Republik Indonesia Tahun 1945 diatur bahwa "Negara mengakui dan menghormati kesatuan-kesatuan masyarakat hukum adat beserta hak-hak tradisionalnya sepanjang masih hidup dan sesuai dengan perkembangan masyarakat dan prinsip Negara Kesatuan Republik Indonesia, yang diatur dalam undang-undang." Berdasarkan ketentuan tersebut tampak jelas bahwa konstitusi telah mengamanatkan agar pengakuan terhadap masyarakat hukum adat beserta hak tradisionalnya diatur dalam ketentuan undang-undang. Namun faktanya sampai saat ini undang-undang yang dimaksudkan belum juga dihadirkan oleh negara untuk memberikan kepastian dan perlindungan hukum bagi masyarakat hukum adat serta hak tradisionalnya, di mana di dalamnya termasuk juga tanah-tanah adat yang menjadi hak tradisional masyarakat hukum adat.

Ketiadaan undang-undang yang diatribusi langsung oleh Undang-Undang Dasar tersebut, tidak menyurutkan eksistensi desa pakraman di Bali untuk tetap menjaga eksistensi tanah-tanah prabumian yang dikekolanya. Eksistensi tersebut tercermin dari unsur-unsur dari desa pakraman yang masih tetap terjaga eksistensinya. Berdasarkan ketentuan Pasal 1 angka 3 Peraturan Menteri Agraria/Kepala Badan Pertanahan Nasional Nomor 5 Tahun 1999 menyebutkan bahwa masyarakat hukum adat adalah "sekelompok orang-orang yang terikat oleh hukum adatnya sebagai warga bersama suatu persekutuan hukum karena persamaan tempat tinggal ataupun berdasarkan atas keturunan". Desa pakraman sebagai kesatuan masyarakat hukum adat mempunyai ketentuan adat (awig-awig) yang masih dipatuhi dan dilaksanakan oleh anggota dari masyarakat hukum adat. Masih dilakasanakannya ketentuan-ketentuan hukum adat tersebut, memberikan gambaran nyata bahwa suatu masyarakat hukum adat masih ada dan tentunya pengaturan mengenai tanah-tanah adat juga menjadi bagian yang tidak terpisahkan dari ketentuan-ketentuan adat tersebut. 
Sejauh ini pengakuan terhadap masyarakat hukum adat (termasuk tanah prabumian) dilakukan secara parsial yang tersebar dalam berbagai peraturan perundang-undangan, mulai dari undang-undang sampai dengan peraturan daerah yang senyatanya tidak sinkron dan cenderung tumpang tindih, sehingga tidak memenuhi hierarki pembentukan peraturan perundang-undangan. Padahal, sejak tahun 1960 tepatnya dalam Undang-Undang Nomor 5 Tahun 1960 tentang Peraturan Dasar Pokok-Pokok Agraria (UUPA) telah mengakui eksistensi hukum adat sebagai hukumnya masyarakat hukum adat. Konsepsi dari ketentuan tanah adat mengenai pola penguasaan tanah adat telah menjadi sumber utama dalam pembangunan hukum tanah nasional. Konsepsi tersebut adalah konsepsi komunalistik religius. Oleh karena itu, sangat perlu untuk memberikan kepastian hukum yang lebih konstruktif dan lebih hirarkis terhadap pengakuan dan perlindungan masyarakat hukum adat (termasuk desa pakraman di Bali) dan tanahtanah adatnya, melalui peraturan undang-undang sesuai dengan hierarki peraturan perundang-undangan. Sehingga nantinya dapat diharapkan memberikan perlindungan dan kepastian hukum yang utuh dan tentunya diharapkan mampu untuk menyelesaikan sengketa pertanahan yang melibatkan masyarakat hukum adat dengan tanah adatnya.

Jelas dalam uraian tersebut memposisikan hukum sebagai instrumen atau alat yang dapat merekayasa kehidupan sosial masyarakat, sebagaimana maksud dari law as a tool of social engineering sebagai sarana rekayasa kehidupan sosial masyarakat (Fuady, 2013: 249). Tentu saja rekayasa kehidupan sosial yang diharapkan adalah kehidupan sosial yang damai, tenteram, sejahtera, dapat memberikan kepastian hukum serta mampu untuk menjaga keutuhan Negara Kesatuan Republik Indonesia menghindarkan kehidupan sosial tersebut dari chaos dan disintegrasi bangsa. Memberikan pengakuan dan perlindungan hukum terhadap masyarakat hukum adat tentunya juga secara tidak langsung akan berpengaruh terhadap eksistensi dari tanah-tanah ulayatnya dan tentu saja juga dapat memberikan kedamaian, ketentraman, kesejahteraan dalam kehidupan sosial masyarakat hukum adat.

\section{Pola Penguasaan Tanah Prabumian Oleh Krama Desa Pakraman di Bali Berdasarkan Konsepsi Komunalistik Religius}

Dalam setiap kehidupan manusia di mana pun ia berada, tanah mempunyai peran yang sangat penting dalam menopang dan menunjang seluruh aspek kehidupan yang dijalani. Demikian pula bagi kehidupan masyarakat hukum adat di Bali yang masih kental hubungannya secara fungsional dengan tanah-tanah adatnya. Tanah tidak hanya berperan sebagai tempat untuk mendirikan rumah akan tetapi tanah juga berfungsi sebagai tempat untuk mengambil segala sesuatu sebagai sumber kehidupan.

Dalam hubungan hukumnya antara manusia sebagai bagian dari masyarakat hukum adat di Bali dengan hukum adatnya sendiri, juga terhadap tanah yang dikuasainya adalah terikat dalam suatu hubungan yang tidak dapat dipisahkan. Oleh karena itu, disebutkan bahwa manusia dikatakan tidak terlepas dari tanah karena tanah adalah tempat untuk tinggal dan sekaligus sebagai sumber kehidupan bagi 
keluarga dan masyarakat, sebagai tempat peristirahatan terakhir bagi anggota masyarakat yang meninggal dan dipercayai pula bahwa pada tanah tersebut juga tempat bersemayamnya Dewa-Dewa dan tempat bersemayamnya roh-roh para leluhur mereka. Dalam pandangannya, Nurhasan Ismail berpendapat bahwa mempunyai tanah itu sangat terkait dengan harga diri, kekuasaan dan pula sangat erat hubungannya dengan nilai-nilai spiritual atau dengan kata lain jika tidak mempunyai tanah maka manusia akan kehilangan harga diri, sumber hidup, jauh dari kekuasaan, dan yang tidak kalah pentingnya adalah kehilangan penghubung antara manusia dengan Tuhan (Ismail, 2012: 34).

\section{a. Sifat Komunalistik Penguasaan Tanah Prabumian}

Bagi krama desa pakraman di Bali, hubungannya yang sangat erat dengan tanah adalah suatu hal yang harus tetap untuk dipertahankan. Berdasarkan hal tersebut di atas, maka untuk melangsungkan kehidupannya sudah barang tentu krama desa pakraman perlu untuk menguasai sebidang tanah. Penguasaan atas tanah tersebut dapat terjadi dengan menguasai tanah prabumian (tanah ulayat). Penguasaan tanah semacam ini merupakan penguasaan secara individu atas tanahtanah milik komunal. Pemberian penguasaan tanah prabumian yang merupakan milik komunal desa pakraman, dapat diberikan kepada krama atau anggota masyarakat dari desa pakraman dengan sejumlah kewajiban-kewajiban yang harus dilaksanakan sebagai timbal baliknya kepada desa pakraman.

Menurut Sukirno, milik komunal "merupakan bentuk penguasaan, di mana seseorang (atau keluarga) memanfaatkan tanah tertentu yang hanya merupakan bagian dari tanah komunal desa, yaitu bahwa orang tersebut tidak diberi hak untuk menjualnya atau memindahtangankan tanah tersebut dan pemanfaatannya biasanya digilir secara berkala" (Sukirno, 2012: 24). Implementasi dari penguasaan secara individu atas tanah milik komunal di Bali, secara umum tercermin pada adanya penguasaan atas Tanah Pekarangan Desa (PKD) maupun penguasaan Tanah Ayahan Desa (AYDS). Penguasaan atas tanah tersebut difungsikan oleh krama desa sebagai tempat untuk bermukim dan sebagian digunakan sebagai ladang maupun persawahan yang hasilnya dapat dimanfaatkan sebagai sumber kehidupan keluarganya.

Dalam kaitannya dengan kebutuhan primer krama desa untuk bermukim atau mendirikan tempat tinggal, maka oleh desa pakraman sebagai lembaga adat, krama desa diberikan kewenangan untuk mengelola dan mengatur pemanfaatan dan peruntukan tanah-tanah komunal tersebut, kemudian diberikan kepada krama desa tanah PKD untuk dikuasai secara individu sebagai tempat bermukim. Seperti misalnya di Desa Pakraman Beng, Gianyar menurut Ni Putu Arie Sulastri dan I Gusti Nyoman Guntur, tanah pekarangan desa yang diberikan penguasaannya kepada masyarakat, hanya dipergunakan untuk tempat bermukim dengan menggunakan sikut satak (konsep arsitektur bali yang terdiri dari tempat sembahyang, sebuah bangunan yang berada di sebelah timur, sebuah bangunan yang terletak di sebelah utara, sebuah bangunan yang didirikan di sebelah barat dan bangunan yang berada di sebelah selatan dari areal rumah serta mempunyai fungsinya masing-masing) 
atau yang biasa disebut dengan bangunan rumah adat Bali (Sulastri dan Guntur, 2013: 293). Selain tanah PKD terdapat pula tanah AYDS yang dapat diberikan kepada krama desa untuk menggarap tanah tersebut sehingga memberikan suatu hasil yang dapat dipergunakan untuk menunjang kehidupan sebagai sumber nafkah, dengan ketentuan bahwa ada bagian tertentu yang harus diserahkan kepada desa pakraman sesuai dengan ketentuan yang berlaku sesuai dengan awig-awig di masing-masing desa pakraman.

Pola penguasaan secara individu terhadap tanah-tanah komunal tersebut dapat dicontohkan terjadi di beberapa desa pakraman di Bali. Desa Pakraman Panestan, Ubud dengan tegas mengatur hubungan krama desanya dengan tanahtanah milik komunal beserta kewajiban yang melekat atas hubungan penguasaan tersebut. Dalam Pawos 4 awig-awig (peraturan adat yang dibuat dan disepakati bersama sebagai pedoman dalam menjalankan kehidupan di suatu desa pakraman atau banjar pakraman, yang dibuat dalam bentuk tertulis, untuk mengatur ketertiban) disebutkan bahwa sane kabaos Krama Desa Pekraman Penestanan inggih punika sahananing kulawarga sane ngamong karang utawi jumenek mapaumah ring wewidanga Desa Pekraman Penestanan sane meagama Hindu pemekasnya kulawarga sane nyungsung Kahyangan Tiga Desa Pekraman Penestanan, saha satinut ring sahaning awig -awig Desa utawi Banjar lan pemargin Krama Desa Pekraman Penestaan (keluarga yang tinggal di Desa Penestan yang beragama Hindu yang berkewajiban untuk ngayah di Kahyangan Desa dan mentaati awig-awig yang dimiliki oleh Banjar atau desa Pekraman Penestanan. Namun, ada juga beberapa tanah pekarangan desa yang sudah diserahkan kepada krama desa untuk dikelola, akan tetapi penguasaannya tetap dalam penguasaan desa pakraman) (Putra, et.al., "Jual Beli Tanah Pekarangan Desa (PKD) Studi Kasus di Desa Pakraman Panestan, Kecamatan Ubud, Kabupaten Gianyar", (http://download.portalgaruda.org/article.php?article=83013\&val=908), diakses 07 Februari 2016).

Ketentuan serupa juga terdapat dan berlaku bagi krama Desa Pakraman Kemenuh, Gianyar. Namun, Desa Pakraman Kemenuh menggunakan istilah karang ayah untuk menamai tanah PKD, dalam ketentuan Sargah IV Indik Karang Ayah Paos Papat awig-awig Desa Pakraman Kemenuh ditentukan bahwa "sane keanggeh karang ayah punika, pekarangan sane ngawentenang hak lan kewajiban merepe ring sane ngenahin minakadi i krama adat Banjar" (yang disebut karang ayah adalah pekarangan yang terdapat hak dan kewajiban bagi yang mendiami yaitu warga adat banjar).

Demikian pula di Desa Pakraman Tusan, Kabupaten Klungkung yang mengenal hubungan penguasaan secara individu oleh krama desa terhadap tanah-tanah komunal atau tanah ulayat. Dalam Pawos 27 awig-awig Desa Pakraman Tusan ditentukan bahwa "krama desa pengemong karang desa patut ngawatesin karang inucap sanistane antuk pagehan utawi tembok mangde pakantanenania asri" (warga desa yang menguasai tanah pekarangan desa wajib membatasi tanah tersebut paling tidak dengan pembatas atau tembok agar asri) (Suwitra, 2010: 96). 
Penguasaan tidaklah dapat diartikan sama dengan kepemilikan. Sehingga penguasaan atas tanah-tanah komunal bagi masyarakat hukum adat di Bali adalah hubungan penguasaan bukanlah pemilikan. Menurut I Made Suwitra, dalam hal untuk memberikan makna penguasaan, sebelumnya harus dipenuhi dua unsur, yaitu: pertama adanya kenyataan bahwa subjek menguasai dan menggunakan objek dimaksud dan kedua yang harus terpenuhi adalah adanya sikap batin bahwa subjek dimaksud mempunyai keinginan untuk menguasai maupun menggunakan objek tersebut. Konsekuensi hukum pemegang kedudukan berkuasa mempunyai suatu hak untuk mempertahankan, menikmati, memanfaatkan, dan mendayagunakan benda yang ada dalam penguasaannya dengan tidak meninggalkan kewajibannya (Suwitra, 2010: 65).

Berdasarkan pandangan di atas maka krama desa dari suatu desa pakraman di Bali telah memenuhi kriteria sebagai pihak yang menguasai tanah tersebut. Hal tersebut dapat tercermin secara faktual bahwa ia telah menggunakan tanah tersebut sebagai tempat tinggal atau dimanfaatkan untuk kelangsungan hidupnya. Secara batin, dapat tercermin karena adanya ikatan rasa dengan para leluhurnya karena menempati tanah tersebut secara turun temurun.

Penguasaan terhadap tanah PKD maupun tanah AYDS sejatinya diberikan kepada krama desa yang mampu untuk menjalankan segala bentuk kewajiban yang melekat terhadap tanah-tanah tersebut. Adapun kewajiban-kewajiban yang melekat adalah dalam bentuk melakukan ayah-ayahan kepada desa pakraman. Adanya ayahayahan tersebut juga menjadi suatu indikator jangka waktu penguasaan tanah tersebut oleh seorang krama desa atau keluarganya dan sekaligus sebagai bukti atas penguasaan tanah PKD atau AYDS tersebut. Sepanjang ayah-ayahan tersebut masih dijalankan atau masih ada pihak yang bersedia melanjutkan ayahan termasuk para ahli warisnya, maka penguasaan atas tanah PKD maupun AYDS masih tetap berlangsung dan bahkan akan dikuasai secara turun temurun. Mengenai hubungan penguasaan tanah tersebut dan bentuk kewajiban yang harus dijalankan diatur dalam awig-awig (hukum adat tertulis) pada masing-masing desa pakraman.

Berdasarkan uraian di atas dapat disimpulkan bahwa dalam hubungan intra komunal antara masyarakat hukum adat secara komunal dan individu (person) masing-masing anggota masyarakat, pola penguasaan yang berlaku adalah pola penguasaan yang timbal balik antara hak bersama masyarakat hukum adat dan hakhak individu masing-masing anggota masyarakat hukum adat. Penguasaan tanah prabumian secara individu oleh krama desa suatu desa pakraman selalu tetap mengandung unsur kebersamaan (komunal).

\section{b. Sifat Religius Pada Penguasaan Tanah Prabumian}

Pada hakikatnya untuk memahami eksistensi tanah-tanah milik komunal pada masyarakat hukum adat di Bali, terlebih dahulu harus dipahami bahwa tanah-tanah tersebut merupakan bagian yang tidak terpisahkan dari unsur palemahan yang merupakan suatu cerminan dari suatu ajaran Agama Hindu yang kemudian lebih dipahami dengan konsep Tri Hita Karana. Dengan penerapan konsep yang 
bersumber pada ajaran agama, nampak jelas tersirat sifat religius pada penguasaan tanah-tanah adat di Bali oleh krama desa pakraman.

Tri Hita Karana merupakan suatu konsep keseimbangan dari ajaran filsafat Agama Hindu, yang dimaknai sebagai keselarasan yang bertujuan untuk mencapai suatu keharmonisan hubungan antara manusia dengan Tuhan (Ida Sang Hyang Widhi Wasa) atau unsur parahyangan, hubungan antara manusia dengan manusia atau unsur pawongan dan hubungan antara manusia dengan lingkungannya atau unsur palemahan. Ketiga unsur tersebut menjadi suatu kesatuan sistem dalam kehidupan manusia, yang dapat menimbulkan suatu disharmonisasi apabila satu dari tiga unsur tersebut diabaikan. Untuk mewujudkan keharmonisan tersebut, maka ajaran Tri Hita Karana ini menjadi pedoman bagi suatu desa pakraman dalam menjalankan tata kehidupan yang dijabarkan dalam awig-awig desa pakraman.

Unsur palemahan adalah salah satu bagian dari konsep Tri Hita Karana tersebut yang terwujud dalam wilayah yang dapat berupa tanah-tanah ulayat dari desa pakraman. Dalam Pasal 1 angka 4 Peraturan Daerah Provinsi Bali Nomor 03 Tahun 2001 tentang Desa Pakraman diatur bahwa Desa Pakraman adalah kesatuan masyarakat hukum adat di Provinsi Bali yang mempunyai satu kesatuan tradisi dan tata krama pergaulan hidup masyarakat umat Hindu secara turun temurun dalam ikatan kahyangan tiga atau kahyangan desa yang mempunyai wilayah tertentu dan harta kekayaan sendiri serta berhak mengurus rumah tangganya sendiri.

Berdasarkan dari ketentuan di atas dapat ditemukan unsur-unsur yang membentuk suatu desa pakraman. Paling tidak terdapat 3 (tiga) unsur utama di dalamnya, yaitu tata krama pergaulan hidup masyarakat Hindu, adanya ikatan kahyangan desa, dan mempunyai wilayah. Sejalan dengan hal tersebut, Wayan P. Windia menuturkan bahwa unsur-unsur yang terdapat dalam desa pakraman terdiri dari tiga unsur yang terkandung dalam Tri Hita Karana, yaitu unsur parahyangan yang dapat disimbolkan dengan adanya Pura Kahyangan Tiga dan Pura Kahyangan Desa, unsur pawongan disimbolkan dengan adanya tata pergaulan masyarakatnya dan palemahan terdiri dari karang ayahan desa (istilah lain dari tanah PKD dan AYDS) dan wewengkon (wilayah desa pakraman) (Windia, 2010: 18-19).

Memahami konsep tersebut di atas dan bagaimana implementasinya dalam kehidupan masyarakat hukum adat di Bali, maka pandangan yang memahami bahwa ideologi sentralisme hukum (legal centralism) dalam pembangunan hukum nasional adalah suatu kemustahilan, karena pranata-pranata hukum selain hukum negara (state law) tetap hidup dalam kehidupan masyarakat, sehingga hukum adat dan hukum agama tetap hidup berdampingan dengan hukum negara dan bahkan mempengaruhi satu sama lainnya.

Kaitannya dengan penguasaan tanah-tanah PKD dan AYDS secara individu oleh krama desa, juga merupakan salah satu wujud dari penerapan ajaran keselarasan tersebut di atas. Perwujudan konsep Tri Hita Karana dalam penguasaan tanah tersebut tercermin dari adanya suatu pemahaman bahwa dengan diberikannya penguasaan tanah PKD dan AYDS kepada masing-masing krama desa yang mampu untuk menjalankan ayahan dengan luas yang sama sebagai tempat 
untuk bermukim dan sebagai sumber nafkah, akan tercipta kesejahteraan. Ketika apa yang disebut dengan kesejahteraan dapat terpenuhi maka kehidupan sosial krama desa diyakini akan dipenuhi dengan rasa nyaman, aman dan tertib sehingga keselarasan menuju keharmonisan dalam unusur pawongan dapat tercapai.

Penerapan unsur parahyangan dalam penguasaan tanah PKD tercermin dalam dua wilayah. Dalam wilayah yang lebih kecil yaitu di dalam kehidupan keluarga, terdapat kepercayaan bahwa pemerajan (tempat suci dalam lingkungan rumah umat Hindu di Bali) yang didirikan di atas pemukiman harus tetap diurus secara berkesinambungan, karena adanya kepercayaan di tempat tersebut beristana Ida Sang Hyang Widhi Wasa beserta manifestasi-Nya termasuk juga tempat diistanakannya roh para leluhur. Kemudian dalam wilayah yang lebih besar yaitu hubungan individu dan keluarga yang menguasai tanah adalah adanya suatu kewajiban untuk melaksanakan ayah-ayahan pada saat dilaksanakan upacara Dewa Yadnya (koban suci secara tulus ikhlas yang dipersembahkan kepada Ida Sang Hyang Widhi) di Pura Kahyangan Tiga maupun Pura Kahyangan Desa di desa pakraman setempat. Adanya kewajiban semacam ini, bukanlah hanya sekedar menjalankan suatu kewajiban saja, namun adanya upaya pembinaan hubungan yang selaras antara krama desa dengan Tuhan (Ida Sang Hyang Widhi Wasa) untuk mencapai kehidupan yang harmonis pula.

Hubungan keselarasan antara krama desa dengan lingkungannya juga dapat terwujud dengan penguasaan tanah PKD maupun AYDS. Dalam hal ini penguasaan dimaksudkan agar dikelola dan diolah dengan baik guna kepentingan sosial, ekonomi, dan religius. Di samping itu, penguasaan tanah-tanah tersebut dibatasi dengan ketentuan awig-awig yang melarang kepada individu yang menguasai untuk mengalihkannya kepada pihak lain tanpa adanya persetujuan berdasarkan paruman desa pakraman (rapat desa) yang bertujuan untuk tetap menjaga kelestarian dan ketersediaan tanah agar tidak terjadi alih fungsi lahan termasuk juga tanah sebagai komoditi perdagangan.

Atas dasar tersebut, maka konsep penguasaan tanah PKD dan AYDS dapat dipahami mempunyai berbagai fungsi. Tanah-tanah tersebut yang tergolong ke dalam tanah-tanah komunal atau ulayat (bagian Hak Ulayat) melekat fungsi keagamaan (religius), fungsi social, dan fungsi ekonomi yang diperoleh dari pengolahan hasil tanah (Mandala, 2011: 116). Demikian pentingnya fungsi tanah PKD dan AYDS bagi krama desa, diharapkan agar fungsi-fungsi tadi tidak menghilangkan aspek komunal dari tanah tersebut. Seperti telah diuraikan sebelumnya bahwa tanah-tanah tersebut pada dasarnya mengandung konsepsi komunalistik religius. Konsepsi komunalistik religius oleh Boedi Harsono dimaknai sebagai suatu konsep "yang memungkinkan penguasaan tanah secara individual, dengan hak-hak atas tanah yang bersifat pribadi, sekaligus mengandung unsur kebersamaan" (Harsono, 2008: 181). Penguasaan tanah adat secara individu yang dikuasai oleh anggota masyarakat hukum adat dalam hal ini adalah krama desa pakraman, sekalipun dikuasai secara individu, namun masih tetap terkandung unsur kepunyaan bersama (komunal). Pendapat di atas nampaknya sejalan dengan teori 
hak milik Grotius menurut paham hukum kodrat yang menjelaskan bahwa segala sesuatu dalam alam sebagai milik bersama dan hak milik secara individu adalah dalam pemahaman hak untuk menggunakan kepunyaan bersama (Suwitra, 2010: 70).

\section{KESIMPULAN DAN SARAN}

\section{Kesimpulan}

Berdasarkan uraian di atas dapat disimpulkan bahwa eksistensi masyarakat hukum adat sangat berpengaruh terhadap penguasaan tanah prabumian berdasarkan konsepsi Komunalistik religius di Bali. Lemah atau kuatnya eksistensi tanah adat dapat disebabkan oleh beberapa faktor. Pertama adalah hilangnya eksistensi masyarakat hukum adatnya sendiri. Kedua adalah menurunnya ketaatan masyarakat hukum adat terhadap peraturan-peraturan hukum adat dan lembaga adatnya. Apabila eksistensi masyarakat hukum adat tersebut telah hilang maka secara tidak langsung akan menyebabkan ketentuan-ketentuan hukum adat yang wajib untuk dipatuhi tidak dapat diberlakukan lagi. Demikian pula mengenai ketentuan tanah-tanah prabumiannya akan secara otomatis tidak dapat diberlakukan lagi. Faktor tersebut dapat menjadi faktor internal yang berpengaruh terhadap eksistensi tanah adat (tanah prabumian).

Ketika masyarakat hukum adat (desa pakraman) tetap ada, maka masyarakat hukum adat (krama desa) dapat dilimpahkan penguasaan atas tanah prabumian. Adapun penguasaan tersebut dilandasi oleh konsepsi komunalistik religius. Cerminan konsepsi tersebut dapat dilihat pada pola penguasaan tanah-tanah prabumian. Unsur komunalistiknya masih tetap mengandung unsur kebersamaan, karena hak penguasaan bukanlah hak milik. Artinya, diberikannya penguasaan tanah PKD kepada krama desa untuk dikuasai secara individu sebagai tempat bermukim dan tanah AYDS untuk digarap dalam rangka memberikan hasil yang dapat dipergunakan untuk menunjang kehidupan sebagai sumber nafkah, dengan ketentuan bahwa ada bagian tertentu yang harus diserahkan kepada desa pakraman. Di samping itu wujud dari adanya unsur kebersamaan dari tanah-tanah tersebut adalah penguasaan tanah-tanah tersebut dibatasi dengan ketentuan awig-awig yang melarang individu yang menguasai untuk mengalihkannya kepada pihak lain tanpa adanya persetujuan berdasarkan paruman desa (rapat desa).

Mengenai unsur religius tercermin dari adanya suatu kepercayaan bahwa pemerajan (tempat melakukan persembahyangan di rumah) yang didirikan di atas pemukiman harus tetap dijaga karena berstana Ida Sang Hyang Widhi Wasa beserta manifestasi-Nya termasuk juga distanakannya roh para leluhur. Kemudian dalam wilayah yang lebih besar yaitu hubungan individu dan keluarga yang menguasai tanah adalah adanya suatu kewajiban untuk melaksanakan ayah-ayahan pada saat dilaksanakan upacara Dewa Yadnya di Pura Kahyangan Tiga di desa pakraman setempat sebagai tempat berstananya Ida Sang Hyang Widhi dalam manifestasinya sebagai Dewa Brahma, Dewa Wisnu dan Dewa Siwa. Penguasaan tersebut sejujurnya juga tidak dapat terlepas dari pengaruh konsep Tri Hita Karana yang berasal dari 
ajaran Agama Hindu, yaitu unsur palemahan, unsur parhyangan, dan pawongan. Ketiga unsur tersebut mempengaruhi dan memberikan dampak pada pola penguasaan tanah-tanah prabumian di Bali.

\section{Saran}

Dalam rangka menjaga eksistensi dari tanah-tanah prabumian di Bali beserta konsepsinya yang adi luhung maka, penulis menyarankan kepada krama desa pakraman (masyarakat hukum adat di bali) agar tetap menjaga eksistensi masyarakat hukum adatnya, sehingga eksistensi dari tanah-tanah prabumiannya juga tetap terjaga. Kemudian, tidak kalah pentingnya saran juga ditujukan kepada pembentuk peraturan perundang-undangan agar segera memberikan pengakuan dan perlindungan hukum yang lebih kuat melalui pembentukan undang-undang sesuai dengan amanat konstitusi, untuk dapat menjamin kepastian hukum bagi masyarakat hukum adat di seluruh Indonesia beserta hak-hak tradisionalnya termasuk di dalamnya hak terhadap tanah adatnya. Karena masyarakat hukum adat juga bagian dari Negara Indonesia dan Bangsa Indonesia yang juga mempunyai hakhak asasi yang harus diberikan perlindungan hukum.

\section{DAFTAR PUSTAKA}

\section{A. BUKU, JURNAL, DAN MAKALAH}

Budiana, I Nyoman, 2011, Memahami Otonomi Desa Pakraman Sebagai Kesatuan Masyarakat Hukum Adat di Bali (Kajian Dari Perspektif Hirarki PerundangUndangan Indonesia), Jakarta Pusat, Jurnal Konstitusi Vol. I, Nomor 1, Juni.

Fuady, Munir, 2013, Teori-Teori Besar (Grand Theory) Dalam Hukum, Jakarta, Kencana.

Harsono, Boedi, 2008, Hukum Agraria Indonesia Sejarah Pembentukan UndangUndang Pokok Agraria, Isi dan Pelaksanaannya, Edisi Revisi, Jakarta, Djambatan.

Hendriatiningsih S, Budiartha A, Andri Hernand, 2008, Masyarakat dan Tanah Adat di Bali (Studi Kasus Kabupaten Buleleng, ProvInsi Bali), Jurnal Sosio Teknologi ITB, Edisi 15 Tahun 7, Desember.

Ismail, Nurhasan, 2012, Arah Politik Hukum Pertanahan dan Perlindungan Kepemilikan Tanah Masyarakat, Jakarta, Jurnal Rechsvinding, Vol. 1 Nomor 1, April.

Mandala I Gusti Partana, 2011, Eksistensi Desa Adat Dalam Penguasaan dan Pemanfaatan Tanah Adat di Bali, Denpasar, Jurnal Hukum, FH Uiversitas Pendidikan Nasional, Vol. 7 Nomor 2 November.

Nurjaya I Nyoman, 2014, Paradigma Pembangunan Hukum Nasional Dalam Masyarakat Multikultural : Perspektif Antropologi Hukum, Denpasar, Jurnal Hukum Undiknas, Fakultas Hukum Undiknas, Vol. 1 No. 1 Agustus. 
Santoso, Urip, 2010, Hukum Agraria dan Hak-Hak Atas Tanah, Cetakan Ke 6, Jakarta, Kencana Prenada Media.

Sukirno, 22 Desember 2012, Dinamika Relasi Hukum Negara Dengan Hukum Adat (Studi Kasus Pengakuan Hak Ulayat Atas Tanah), Makalah pada seminar Hubungan Hukum Negara, Hukum Adat dan Hukum Agama di Negara Asia dan Asia Tenggara, Semarang, Fakultas Hukum, Universitas Diponegoro.

Sulastri, Ni Putu Arie dan Guntur, I Gusti Nyoman, 2013, Sistem Tenurial Tanah Adat Di Bali: Studi Tanah Pekarangan Desa Di Desa Pakraman Beng, Yogyakarta, Pusat Penelitian dan Pengabdian Masyarakat Sekolah Tinggi Pertanahan Nasional, Bhumi Jurnal Ilmiah Pertanahan, Nomor 38 Tahun 12, Oktober.

Suwitra, I Made, 2010, Eksistensi Hak Penguasaan dan Pemilikan Atas tanah Adat di Bali, dalam Perspektif Hukum Agraria Nasional, Bandung, LoGoz Publishing.

Wiguna, I Gusti Ngurah Tara, 2009, Hak-Hak Atas Tanah Pada Masa Bali Kuna Abad X-XI Masehi, Cetakan Pertama, Denpasar, Udayana University Press.

Windia, Wayan P., 2010, Bali Mawacara Kesatuan Awig-Awig, Hukum dan Pemerintahan di Bali, Denpasar, Udayana University Press.

\section{B. INTERNET}

Putra Made Adi Berry Kesuma, Parwata A.A. Gde Oka, Dewi A.A. Istri Ari Atu, diakses 07 Pebruari 2016, "Jual Beli Tanah Pekarangan Desa (PKD) Studi Kasus di Desa Pakraman Panestan, Kecamatan Ubud, Kabupaten Gianyar"(http://download.portalgaruda.org/article.php?article=83013\&val $=908$.) 